\title{
Venture Helps Artisans with Special Needs Find Markets
}

\section{Kimberly Eddleston (Northeastern University)}

\begin{abstract}
KEYWORDS: Entrepreneurship, social entrepreneurship, efest2019.

Yad, an eFest2019 finalist company, has a social mission at its heart: it aims to help Guatemalan artisans with special needs express themselves through art, and then find retailers who can help them reach markets for their work. In this video, Yad founder and Babson College graduate Deborah Cohen talks with EIX's Kim Eddleston about her mission and her journey so far.
\end{abstract}

Additional Search Terms: eFest, student entrepreneurs, mission-driven, helping others

To learn more about eFest, EIX's competition for undergraduate business ideas, click here (https://eix.org/e-fest-guide/) . 